\title{
«Международное правовое регулирование отношений недропользования: Сборник международных правовых актов». Институт законодательства и сравнительного правоведения при Правительстве Российской Федерации. Составители сборника: Н.А. Сыродоев, О.М. Теплов, М.В. Веремеева, И.И. Толстых. М.: Изд-во «Олита», 2005. 448 с.
}

Малеев Ю. $H^{*}$
Гликман О.В.*

Зикиряходжаев Л.Д."**

Собственно рецензией нашу пуббликацию не назовешь. Да и какая может быть рецензия на сбоорник документов, которые сами по себе такие, какие есть. Наша публликация, скорее, вынужденный отклик на «вступление» к данному сборнику, которое по ряду причин вызывает нелицеприятную оценку. И это при том, что помещенные в сборнике документы в самом позитивном смысле не могут не привлекать внимания широкого круга читателей: слишком актуальна тематика. Отношения недропользования сегодня все более обостряются (самый адекватный термин) прежде всего в связи с такими энергетическими источниками, как нефгь игаз. Запасыпоследних давно подсчитаны, грозят полным истощением через 20-25 лет, и в этих условиях интенсификация их добычи и продажи порождает больше тревоги, чем восторга перед могуществом человека, особенно если учесть, что альтернативных источников энергии в промышленных масштабах человечество пока не выработало. (И в отношении российских нефтедолларов на этом фоне оптимизма становится меньше).

\footnotetext{
* Малеев Юрий Николаевич - д.ю.н., профессор кафедры международного права МГИМО (У) МИД Россин.

Гликман Ольга Владимировна - к.ю.н., старший преподаватель кафедры международного права МПИМО (У) МИд России.

Зикиряходжаев Лазис Дильшадович - аспирант кафедры международного права МГИМО (У) МИД Россин.
} 
Оптимальное правовое регулирование ресурсосбережения и ресурсопотребления - вот, пожалуй, наиболее актуальный (хотя, казалось бы, производный) аспект рассматриваемой проблематики. Аспект, который, даже при идеальной постановке соответствующих дел, по некоторым оценкам, не в состоянии спасти мир от грядущей катастрофы. В этом плане перестаешь расценивать как циничное или поверхностное высказывание американских аналитиков о том, что национальная безопасность страны зависит от «устойчивого снабжения природными ресурсами» и вполне вероятна «война за природные ресурсы $\rangle^{1}$.

В этом контексте любое юридическое издание по вопросам добычи природных ресурсов и недропользования, в том числе принадлежащее перу специалистов в области внугригосударственного права, ${ }^{2}$ сразу же оказывается востребованным и специалистами в области международного права. Данный сборник, который мы «рецензируем», подготовлен лицами, не владеюгцими некоторыми азами международного права, несмотря на многообещающее (хотя и спорное - см. далее) название работы. Но, тем не менее, он весьма полезен в практическом плане тем, что обостряет общественный интерес к этой наиважнейшей теме.

Если совсем кратко, то в данном сборнике систематизированы основные (далеко не все) международно-правовые акты, характеризугщие современный статус недр и международно-правовой режим недропользования. Хотя название издания в этом отношении нельзя признать удачным.

Что значит «международное правовое регулирование»? Большинство и специалистов, и «не специалистов» видят в этом противопоставление давно устоявшемуся понятию «международно-правовое ре-

${ }^{1}$ Campbell-Mohn C., Breen B., Futrel J.W. Environmental Law. From Resources to Recovery. St. Paul, 1993, Ориентируясь на целевую программу США - «Обращаясь лицом к морю: океанское будущее Америки» (в плане морских разработок нефти и газа), Президент США заявил в 2001 году, что США должны стать «энергетически независимыми» (См.: The Seattle Times. February 28, 2001 .). Цит. по: А.Н. Вылегжанин. Морские природные ресурсы (международно-правовой режим). М., 2001 . С. 14. Вылегжанин А.Н., Гуреев С.А., Иванов Г.Г. Международное морское право. М., 2003. C. 329.

${ }^{2}$ См., например: Клюжин Б.Д. Горные отношения в странах Западной Европы и Америки. М., 2000. 444 с. Крассов О.Н. Комментарий к Закону Российской Федерации «О недрах». М., 2003. 478 с. РАЕН. Правовой режим минеральных ресурсов. Словарь / Под ред. А.А. Арбатова и др. М., 2002. 284 с. 
гулирование» как более узкому по сравнению с понятием, используемым авторами сборника. Соответственно «международное правовое» регулирование настраивает на «побое» правовое регулирование, встречающееся в мире: внутригосударственно-правовое (национальноправовое), межлународно-правовое, коммунитарное, транснациональное, комплексное (разные термины блуждают сегодня в правовой доктрине).

(И.3. Фархутдинов, защитивший в 2006 году докторскую диссертацию, полагаег, например, что основу международного инвестиционного права составляет совокупность международно-правовых и национально-правовых норм, регламентируюших отношения между различными участниками инвестиционной деятельности на территории чужого государства. ${ }^{3}$ То есть, по его мнению, «международно-правовая часть» международного инвестиционного права сосуществует с национально-правовой его частью в рамках единого «международного» инвестиционного права. И, соответственно, национально-правовые нормы в данном случае при таком подходе - тоже «международное инвестиционное право». Отсюда совсем «естественен» переход к такому толкованию, что «международное правовое регулирование», в отличие от международно-правового регулирования, охватывает любое правовое, в том числе национально-правовое, регулирование в рамках определенных отношений по поводу...).

Словом, надо аккуратней с терминологией. Ведь ознакомление с содержанием сборника однозначно свидетельствует о том, что его составители ничего иного не имели в виду, кроме международноправовых актов (а не «международных правовых» актов). Так и надо выражаться.

Структурно сборник состоит из вступления (с. 3-26) и двух разделов: «Многосторонние соглашения в области недропользования» (с. 29-353) и «Двусторонние соглашения в области недропользования» (с. 355-439).

Вступление $^{4}$ представляет собой краткий комментарий составителей сборника к некоторым общим вопросам, так сказать, «сопутству-

${ }^{3}$ См.: Фархутдинов И. З. Международное инвестиционное право. Теория и практика применения. М.: Волтерс Клувер, 2005.

${ }^{4}$ Строго говоря, человеку, привыкшему к термину «введение» в научных работах и термин «вступление» представляется неадекватным. Это не всегда синонимы. Вступление неизменно является интегральной частью произведения (сравните: «Вступление к опере...». Никто никогда не скажет «Введение к опере...»). В то время как рецензируемый сборник мог быть опубликован без единого «вступительного слова» и при этом ничуть не пострадал бы (а может, и вынграл бы). 
ющим» помещенному в сборнике материалу. В частности, отмечается важность и роль международных договоров Российской Федерации в ее правовой системе, называются основные проблемы международно-правового регулирования недропользования, дается представление о значении ключевьх международньх договоров, включенных в сборник.

Показательно, что составители начинают свой комментарий с проблематики добычи и использования морских недр, включая недра дна внутренних морских вод, территориального моря, континентального шельфа и т.д. Это имеет определенную логику, поскольку в последние годы морские недра пользуются повышенным вниманием политиков, экономистов и, соответственно, юристов ${ }^{5}$.

Отечественная школа международного права, представленная в данном направлении Ю.Г. Барсеговым, А.Н. Вылегжаниным, Г.Ф. Калинкиным, А.Л. Колодкиным, М.И. Лазаревым, С.В. Молодцовым и другими, в этом плане выработала некоторые устойчивые позиции, которых желательно придерживаться. Но авторы рецензируемого сборника во вступлении проявляют порой «самостоятельный» подход, который походит, скорее, на небрежность, чем на творчество.

Например, на стр. 5 читаем: «Особое значение нормы международного права имеют при использовании недр континентального шельфа Российской Федерации, а также недр морского дна в пределах исключительной экономической зоны, внутренних морских вод и территориального моря, так как их гранищы и правовой режим определяются на основе международных договоров Российской Федерации ... или норм международного права». Ясно, что при таком противопоставлении нормы, содержащиеся в международных договорах Российской Федерации, исключаются из разряда норм международного права. А это неправильно.

Не будем углубляться в эту элементарную небрежность, поскольку не можем даже предположить, чтобы составители сборника в данном случае на самом деле думали так, как написали.

Более существенны последующие ошибки. Так, на стр. 5 вступления отмечено: «В соответствии с нормами Конвенции о континентальном шельфе и ст. 1 Федерального закона «О континентальном шельфе РФ» понятие «континентальный шельф Российской Федерации» включает в себя морское дно и недра подводных районов, находящихся за пределами территориального моря Российской Федерации на всем протяжении естественного продолжения ее сухопутной территории до внешней границы подводной окраины материка». 
Во-первых, в Конвенции о континентальном шельфе 1958 г. вообще нет понятия «подводная окраина материка», нет и положений о 200милыном пределе. Термин «внешняя окраина материка», положения о 200-мильном пределе предусмотрены не Конвенцией о континентальном шельфе 1958 г., а Конвенцией по морскому праву 1982 г.

Во-вторых, ошибочно определять «континентальный шельф Российской Федерации» на основе только Конвенции о континентальном шельфе 1958 г. и Федерального закона «О континентальном шельфе». Российская Федерация участвует не только в Конвенции о континентальном шельфе 1958 г., но и в Конвенции ООН по морскому праву 1982 г. Однако в данном контексте, раз уж делается ссылка на Конвенцию о континентальном шельфе 1958 г., надо было: а) корректно ее цитировать; б) указать, в каком соотношении находятся нормы Конвенции 1958 г. и Конвенции 1982 г. (о чем написано много в отечественной и зарубежной юридической литературе). Иначе недостаточно подготовленный читатель вводится в заблуждение.

Сходная ошибка допущена на стр. 6 сборника в следующем тексте: «В соответствии с нормами Конвенции о территориальном море и прилежащей зоне и ст. 2-4 Федерального закона «О внутренних морских водах, территориальном море и прилежащей зоне Российской Федерации» территориальное море Российской Федерации представляет собой примькающий к сухопутной территории Российской Федерации или к внугренним морским водам морской пояс шириной до 12 морских миль». Опять-таки в Конвенции о территориальном море и прилежащей зоне 1958 г. не предусмотрен 12-мильный предел территориальных вод. Это новелла, введенная Конвенцией ООН по морскому праву 1982 г., - неужели это откровение для составителей данного сборника?

На той же стр. 6 читаем: «Прилежащая зона Российской Федерации в соответствии с Конвенцией о территориальном море и прилежащей зоне и ст. 22 Федерального закона «О внутренних морских водах, территориальном море и прилежащей зоне» представляет собой морской пояс, который расположен за пределами территориального моря, прилегает к нему и внешняя граница которого находится на расстоянии 24 морских миль». Однако, чтобы убедиться в ином, достаточно ознакомиться с п. 2 ст. 24 Конвенции о территориальном море и прилежащей зоне 1958 г.: «прилежащая зона не может распространяться за пределы двенадцати миль от исходной линии, от которой отмеряется ширина территориального моря». 24-мильный предел прилежащей 
зоны, опять же, установлен не в Конвенции о территориальном море и прилежащей зоне, а в Конвенции по морскому праву 1982 г.

Кто-то может сказать: «Не ахти какой грех! В конце концов, достаточно ознакомиться с текстом соответствующих конвенций, чтобы все встало на место». Это, конечно, так. Но всем нам хорошо известно правило «экономии времени», к которому сплошь и рядом прибегает студенческая масса, аспиранты и тем более «широкая публика»: узнавать о содержании нормативных документов не по первоисточникам, а в изложении. И не просто узнавать, а в виде своеобразной цепной реакции распространять и далее. Согласитесь, в этой ситуации сборник оказывает плохую услугу.

Далее, четвертый абзац на стр. 7 рецензируемого труда: «В качестве примеров международньх договоров, регулирующих правовой статус и отношения недропользования на континентальном шельфе или в пределах исключительной экономической зоны, можно назвать Декларацию о континентальном шельфе Балтийского моря (от 23 октября 1968 г.)...». Какие основания у составителей сборника квалифицировать декларацию в качестве международного договора - не ясно. Смыслу Венской конвенгци о праве международных договоров 1969 г. это противоречит. (И, опять же, надо пожалеть «неподготовленную аудиторию», которая, прочтя приведенную цитату, будет относиться к разного рода декларациям как к международным договорам. Это уже пусть не преднамеренное, но образование «не в том направлении»).

Не поддается расшифровке следующая мысль на стр. 25: «В российском законодательстве приоритет международных норм наиболее четко закреплен относительно технического регулирования... ». До сих пор российские юристы полагали, что наиболее четко указанный приоритет установлен вторым предложением части 4 ст. 15 Конституции Российской Федерации: «В случае, если международным договором Российской Федерации установлено иное правило, чем предусмотрено законом, применяется правило международного договора». Какое существует более совершенное закрепление данного приоритета, в каком «техническом регулировании»-надо бы пояснить.

${ }^{5}$ См.: Вылегжсанин А.Н. Международно-правовой режим исследований морских природных ресурсов. М.: СОПС, 2002; Вылегжанин А.Н. Морские природные ресурсы (международно-правовой режим). М., 2001. См. также:Вылегжанин А.Н. Недропользование: некоторые теоретические вопросы международного права // Московский журнал международного права. Специальный выпуск. М., 2005. 
По структуре и содержанию Сборника можно также высказать замечания:

- в Сборнике приведена лишь часть ХІ Конвенции ООН по морскому праву 1982 г. - о международном районе морского дна и его ресурсах (с. 74-1 14). В то же время за рамками сборника осталось Соглашение об́ осуществлении части ХI Конвенции ООН по морскому праву 1982 г. ${ }^{6}$, вступившее в силу;

- в шестом параграфе первого раздела сборника объединены тексты международно-правовых актов под общим названием: «Порядок разрешения споров. Возмещение причиненного вреда за ущерб от загрязнения нефтью». Однако кроме трех межлународно-правовьг актов: Межлународной конвенции о гражданской ответственности за ущерб от загрязнения нефтью 1969 г., Международной конвенции о создании Международного фонда для компенсации ущерба от загрязнения нефтью 1971 г. и соответствующих положений Конвенщии ООН по морскому праву в данном разделе ничего не содержится. Необоснованно забыты составителями многие другие договорные источники международного права, не говоря уже об итогах работы Комиссии международного права по вопросам кодификации института ответственности государств;

- упущением следуег считать то, что в сборнике не представлен Договор о Шпицбергене 1920 г. и принятый в соответствии с Договором Горный устав Шпицбергена: толкование их положений имеет практическую значимость в свете конфликтных правопритязаний на углеводороды в северо-западной Арктике .

Но это уже из области пожеланий к возможному переизданию соорника.

В целом же сборник, безусловно, полезен. Тем более что второй раздел сборника «Двусторонние соглашения в области недропользования» не сопровождается ошибочными комментариями во вступлении, а его текстуальная часть свидетельствует о скрупулезной и трудоемкой работе, проведенной составителями. Конечно, в электронных правовых базах данных соответствующая информация представлена полностью. Но не все «заинтересованные лица» имеют доступ к таким базам в принципе или в нужный момент. Поэтому и в «традиционном виде» подобные публикации полезны.

${ }^{6}$ РФ является участницей данного соглашения с 26 февраля 1997 г.

${ }^{7}$ Вылегжанин А.Н. Правовой режим недр дна Северного Ледовитого океана // «Нефть. Газ. Право». 2006. № 2. 
Высказанные нами замечания тем более досадны, что сборник издан Институтом законодательства и сравнительного правоведения при Правительстве Российской Федерации, престижем которого следует дорожить. Объясняются допушенные ошибки просто: издание подготовили сотрудники отдела российского горного права указанного института, не являющиеся специалистами по международному праву. Что ж, в следующий раз за подобные издания лучше браться специалистам. 